International Journal of Instruction

e-ISSN: 1308-1470 • www.e-iji.net
July $2019 \bullet$ Vol.12, No.3

p-ISSN: 1694-609X

pp. $529-540$

Received: 26/11/2018

Revision: 13/04/2019

Accepted: 18/04/2019

OnlineFirst:11/05/2019

\title{
The Implementation of Mentoring Based Learning to Improve Pedagogical Knowledge of Prospective Teachers
}

\section{Nopriyeni}

Student of Post-Graduate Educational Sciences, Yogyakarta State University, Indonesia, nopriyeni.spd2015@student.uny.ac.id

\section{Zuhdan Kun Prasetyo}

Faculty of Mathematics and Natural Sciences, Yogyakarta State University, Indonesia, zuhdan@uny.ac.id

\section{Djukri}

Faculty of Mathematics and Natural Sciences, Yogyakarta State University, Indonesia, djukri@uny.ac.id

Pedagogical competence refers to the teacher's ability related to their theoretical mastery and its application in teaching performance. This ability can be obtained through educational process based on the level of competence. This research aims at comparing the effect of the mentoring model implementation toward pedagogical knowledge of prospective teachers. This study belongs to a quasiexperiment research with pretest- posttest nonequivalent control group design. The population of this research was the prospective students of Biology Education Department in University of Muhammadiyah Bengkulu. The sample of this research was 60 students taken by using cluster sampling technique. The research instrument used a pedagogical knowledge test. The data were analyzed by using Mann-Whitney U-test. The results showed that the implementation of mentoring model has significant different effect in improving pedagogical knowledge compared to the conventional model. Thus, it can concluded that the implementation of mentoring model has a significant effect on the improvement of pedagogical knowledge. The mentoring model has proven to be effective in supporting the teachers' professional development.

Keywords: mentoring, pedagogical knowledge, teachers performance, pedagogical competence, prospective teachers

Citation: Nopriyeni, Prasetyo, Z. K., \& Djukri. (2019). The Implementation of Mentoring Based Learning to Improve Pedagogical Knowledge of Prospective Teachers. International Journal of Instruction, 12(3), 529-540. https://doi.org/10.29333/iji.2019.12332a 


\section{INTRODUCTION}

Teachers' efforts to improve the learning process play an important role in achieving educational goals (Ramdiah et al., (2019). Skilling et al. (2016) clarify that the students' experience in their teachers education will influence their teaching performance in the future. It will also influence teachers' strategies in assisting and motivating their students, which directly affects students' learning outcomes. Teachers must be able to give students the opportunity to understand concepts and make justifications. Interactions between teachers and students in the classroom during the learning process are influenced by formulation of learning objectives (Kusaeri, \& Aditomo, 2019). In line with this, Lee \& Takahashi (2011) mention that the formulation of learning objectives is so important that can be a reference for teachers in designing learning materials.

Pedagogical competence refers to the teacher's ability related to their theoretical mastery and its application in teaching performance. This ability can be obtained through educational process based on the level of competence. Higher education demands the students to improve all their potentials, talents, interests, skills, level of intelligence and those ultimately determine the level of success. According to Mulyasa (2004) there are seven indicators that show poor teacher performance, such as 1) poor understanding of learning strategies, 2) lack of classroom management, 3) lack of experience in conducting and using classroom action research, 4) low motivation, 5) lack of discipline, 6) low professional commitment and 7) poor time management skills. Some of these problems show that it is important to provide model mentoring, especially to improve pedagogical knowledge. This research aims to compare the effect of the implementation of mentoring model in mastering pedagogical knowledge of prospective teachers, especially their pedagogical knowledge. The prospective teachers must understand the approaches to deliver material effectively and also know about curriculum, students' characteristics, and teaching strategies. In this case, pedagogical knowledge helps prospective teachers to master the strategies in science learning as well as to provide beneficial experience for them.

Prospective teachers need to master knowledge about the interaction between pedagogy and content to implement strategies that help students to understand the learning material (Koehler et al. 2013: 2). The knowledge of teaching and learning process as well as practices or methods is usually called Pedagogical Knowledge (PK). It is knowledge about teaching methods and processes, including knowledge of managing classes, providing assessment, developing lesson plans and learning processes (Schmidt et al., 2009). In line with this, Mishra and Mattew (2006) also state that pedagogical knowledge is related to students' learning, classroom management, development and implementation of learning plans, and evaluation. This includes knowledge of the techniques or methods that will be used in the classroom and strategies for evaluating students' progress.

A teacher with deep pedagogical knowledge will understand how to build students' knowledge, skills acquisition, and positive thinking habits towards learning. Thus, pedagogical knowledge requires an understanding of cognitive, social, and learning theories and the way to apply them in classroom. The students who have pedagogical 
knowledge will be able to design and carry out appropriate learning procedure. The prospective teachers must master the learning subject that will be taught to to avoid misconception. As stated by Mishra and Mattew (2006), teachers who do not have an understanding of the learning material will be wrong in representing the learning material to their students. To improve the insight of the students as prospective teachers, they need to take part in mentoring or activities.

The mentoring program is an educational model to improve pedagogical knowledge. It is also useful as a reference material in increasing the professionalism of prospective teachers. Thus, pedagogical knowledge requires an understanding of cognitive, social and developmental learning theories and how to apply them in classroom. Mentoring is interpersonal relationships in the form of care and support between someone who is experienced and knowledgeable with the less experienced ones (Crawford, 2010). The process include modelling because a mentor must be able to be a role model and give advice to the prospective teachers (Gay, \& Airasian, 1995). Mentoring has become an important component to coach them. However, mentors need to give various mentoring models in training so that interactions can occur well. The suitable mentoring model can increase the pedagogical knowledge of prospective teachers which can eventually be implemented in real teaching practice and problem-solving process. The following is the scheme of mentoring models that can be applied.

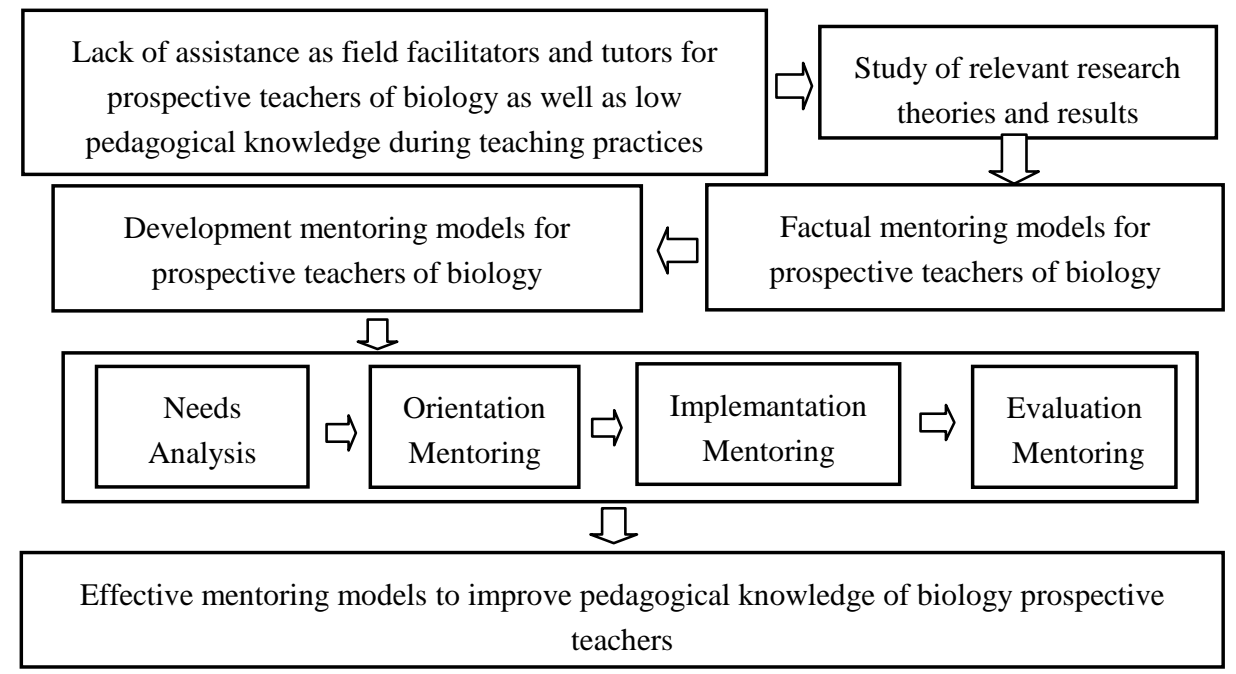

Figure 1

Thinking Frameworks of Mentoring to Improve Pedagogical Knowledge of Biology Prospective Teachers

The mentoring model needs to be studied to determine the application of various contexts for effective teaching. Hudson., Skamp, \& Brooks (2005) suggest five mentoring factors to support teacher competence through the process of real experience. 
Those factors are personal attributes, system requirements, pedagogical knowledge, modeling, and feedback.

Based on the results of preliminary study using observation on the lecturering process in Biology Education Department, University of Muhammadiyah Bengkulu. It is known that the learning process still does not accommodate all the varied learning models, it is still teacher-oriented where the learning is held with full control of the lecturers and low students' involvement. In addition, learning tends to use a conventional approach with the use of lecturing method, papers assignment, general discussion and questionsanswers. It was revealed that the use and development of active learning strategies with various implementations have not been optimally performed. Learning in Biology Education Study Program should present the learning process which is oriented on fulfilling the students' needs to become professional teachers. The interviews results with the teachers' supervisors in the school during teaching practicum showed that the prospective teacher could not apply the effective method of teaching in class with lack of classroom management. The students who are about to face the teaching practicum did not understand the pedagogical knowledge concept even they were confused what should be done in the practice of real teaching though they had experienced of teaching practice in the microteaching course. The learning process in the biology study program as an educational institution of teachers education should be directed to facilitate the students not only in terms of content mastery but also develop pedagogical knowledge comprehensively. In fact, it was done partially so that the prospective teachers have lack of pedagogical knowledge.

To overcome this problem, the mentoring program should be implemented to encourage prospective teachers. This is supported by Lai (2005) who stating that mentoring plays an important role in improving the competence of prospective teachers and providing opportunities for mastering pedagogical knowledge, especially mastery of learning strategies as an important part to emphasize the students involvement to explore knowledge independently (Arnyana, 2007). The pedagogical knowledge as a pedagogic component, should be taught systematically to improve teacher skills in managing their learning process, learning plans and evaluations.

The pedagogical knowledge in this study is the knowledge of teacher competencies about the processes and practices involved in teaching and learning to achieve the overall educational goals. This knowledge consists of knowledge learning processes, individual students' characteristics, classroom assessment, teaching methods, and classroom management. The instruments for increasing students' pedagogical knowledge are arranged based on aspects, descriptions and pedagogical knowledge indicators which are then used to compile the outline as presented in Table 1 below. 
Table 1

The Outlines of Pedagogical Knowledge

\begin{tabular}{|c|c|c|}
\hline Aspects & Description & Indicators \\
\hline $\begin{array}{l}\text { Knowledge of } \\
\text { learning } \\
\text { processes }\end{array}$ & $\begin{array}{l}\text { Knowledge of achieving } \\
\text { competency development based on } \\
\text { certain theories through interaction } \\
\text { within learning stages. }\end{array}$ & $\begin{array}{l}\text { a. Applying learning strategies } \\
\text { b. Ability to provide feedback to } \\
\text { students }\end{array}$ \\
\hline $\begin{array}{l}\text { Knowledge of } \\
\text { individual } \\
\text { characteristics }\end{array}$ & $\begin{array}{l}\text { Knowledge about students' } \\
\text { characteristics based on learning } \\
\text { styles, cognitive abilities and } \\
\text { motivation to achieve learning } \\
\text { goals. }\end{array}$ & $\begin{array}{l}\text { c. Ability to describe knowledge } \\
\text { about cognitive development } \\
\text { students } \\
\text { d. Ability to motivate learning }\end{array}$ \\
\hline $\begin{array}{l}\text { Knowledge of } \\
\text { classroom } \\
\text { assessment }\end{array}$ & $\begin{array}{l}\text { Knowledge of learning assessment } \\
\text { procedures in aspects of formative / } \\
\text { summative assessment, and lesson } \\
\text { evaluation planning in a systematic, } \\
\text { comprehensive, continuous and } \\
\text { objective manner. }\end{array}$ & $\begin{array}{l}\text { e. Ability to make formative and } \\
\text { summative judgments, } \\
\text { f. Ability to plan lesson } \\
\text { evaluations }\end{array}$ \\
\hline $\begin{array}{l}\text { Knowledge of } \\
\text { teaching methods }\end{array}$ & $\begin{array}{l}\text { Knowledge of the use of various } \\
\text { relevant learning methods to } \\
\text { achieve learning objectives which } \\
\text { consist of applying various teaching } \\
\text { methods and knowing when and } \\
\text { how to apply each of these } \\
\text { methods. }\end{array}$ & $\begin{array}{l}\text { g. Applying various teaching } \\
\text { methods, } \\
\text { h. Knowing when and how to } \\
\text { apply each appropriate teaching } \\
\text { method }\end{array}$ \\
\hline $\begin{array}{l}\text { Knowledge of } \\
\text { classroom } \\
\text { management }\end{array}$ & $\begin{array}{l}\text { Knowledge in learning to create a } \\
\text { conducive atmosphere of learning } \\
\text { activities to support the educational } \\
\text { interaction process to achieve } \\
\text { learning goals }\end{array}$ & $\begin{array}{l}\text { i. Creating conducive atmosphere } \\
\text { j. Managing classroom learning } \\
\text { activities }\end{array}$ \\
\hline
\end{tabular}

It is expected that the mentoring program will be useful for lecturers in developing pedagogical knowledge of prospective teachers. Pedagogical knowledge in this paper is the novelty in this research project in which to improve pedagogical knowledge is done by mentoring. Based on the theoretical review and relevant studies, the research questions can be formulated as (1) how is the effectiveness of the mentoring implementation to improve the mastery of pedagogical knowledge for prospective teachers? (2) how is the mentoring implementation implemented by lecturers as a reference for further evaluation programs?

\section{METHOD}

\section{Research Design}

This study belongs to a quasi-experimental research using pretest-posttest nonequivalent control group design. The research population was the sixth semester students of Biology Education Department from University of Muhammadiyah Bengkulu in the academic year of 2017/2018. The sample was consisted of 60 students divided into two 
classes, taken by cluster sampling by classified the population into separate groups, called clusters. Then, a simple random sample of clusters was selected from the population. The experimental class applied the mentoring model and the another class was as the conventional class which was used as the control group. The learning model in the conventional class was done through the traditional models, i.e. lecturing as well as question and answer, and so on. As explained by Djamarah (2010-97) that lecturing method can be called as traditional method because this method has been used as a means of verbal communication between instructors and students in the learning process. This learning models are characterized by lecturing which are then followed by explanation and given tasks both individually and in groups.

Table 2

Design Pre-Test Post-Test Non-Equivalent Control Group

\begin{tabular}{llll}
\hline Group & Pre-test & Treatment & Post-test \\
\hline Experiment & $\mathrm{O}_{1}$ & $\mathrm{X}_{1}$ & $\mathrm{O}_{2}$ \\
\hline Control & $\mathrm{O}_{1}$ & $\mathrm{X}_{0}$ & $\mathrm{O}_{2}$ \\
\hline
\end{tabular}

Information:

$\mathrm{O}_{1}$ : Pre-test of pedagogical knowledge

$\mathrm{O}_{2}$ : Post-test of pedagogical knowledge

$\mathrm{X}_{1}$ : Mentoring model

$\mathrm{X}_{0}$ : Conventional model

The research was conducted for two months in the Biology Education Department, starting from June to July 2018. The implementation of the mentoring model was done based on the stages of the procedure. The classes were held for 190 minutes each meeting per week. The stages of the mentoring program to improve prospective teachers are presented in Table 3 below.

Table 3

The Stages of Mentoring Program to Improve the Pedagogical Knowledge of Prospective Teachers

\begin{tabular}{ll}
\hline \multicolumn{1}{c}{ Stages } & \multicolumn{1}{c}{ Behavior Mentoring } \\
\hline Stage 1 & - Explain learning objectives, and motivate participants to be involved in \\
Preparation & educational activities \\
& - Organize the learning process \\
& - Establish good relationship between mentors and students as well as focus \\
& on mentor preparation for their new roles \\
\hline Stage 2 & - Encourage participants to listen more specific information, to get \\
Implementation & comprehensive explanation. \\
& - Regulate relationship and support active learning \\
& - Maintain enthusiasm in the learning process with monitoring and \\
& - Asaluation processes progress of learning objectives accomplishment. \\
& - Build learning activeness to realize collaboration with students \\
\hline Stage 3 & - Demonstrate behaviors that can be observed and carried out by the students \\
Reflection and & - Assess progress towards learning objectives \\
evaluation & - Reflect learning outcomes \\
\hline
\end{tabular}




\section{Data Collection and Analysis}

The data were collected from the scores test of pedagogical knowledge. The pre-test was carried out in the first week of the research while the post-test was carried out at the end of the research that was the third week of July 2018. A total of 11 test items were used. The tests were made by the researchers and validated by four curriculum and educational experts. The test was in the form of essay (11 items). The score of the essay was between 0,1 and 2 . All the test items were valid with a value of $0.8(\mathrm{p}<.05)$. The coefficient of the Cronbach's alpha test was 0.94 that can be considered as high score of the reliability (Sarwono, 2015). The instrument aspects, descriptions and pedagogical knowledge indicators are presented in Table 4.

Table 4

The Outlines for Pedagogical Knowledge Test Instrument

\begin{tabular}{|c|c|c|c|}
\hline Aspects & Description & Indicators & Item \\
\hline \multirow{3}{*}{$\begin{array}{l}\text { Knowledge of } \\
\text { learning } \\
\text { processes }\end{array}$} & \multirow{3}{*}{$\begin{array}{l}\text { Knowledge achieves } \\
\text { competency development based } \\
\text { on certain theories through } \\
\text { interaction with learning stages. }\end{array}$} & \multirow{3}{*}{$\begin{array}{l}\text { a. Applying learning } \\
\text { strategies } \\
\text { b. Ability to provide } \\
\text { feedback to students }\end{array}$} & 1 \\
\hline & & & 2 \\
\hline & & & 3 \\
\hline \multirow[t]{2}{*}{$\begin{array}{l}\text { Knowledge of } \\
\text { individual } \\
\text { characteristics }\end{array}$} & \multirow{2}{*}{$\begin{array}{l}\text { Knowledge about student } \\
\text { characteristics based on } \\
\text { learning styles, cognitive } \\
\text { abilities and increased } \\
\text { motivation to achieve learning } \\
\text { goals. }\end{array}$} & $\begin{array}{l}\text { c. Ability to describe } \\
\text { knowledge about } \\
\text { cognitive development } \\
\text { students }\end{array}$ & 4 \\
\hline & & $\begin{array}{l}\text { d. Ability to motivate } \\
\text { learning }\end{array}$ & 5 \\
\hline \multirow[t]{2}{*}{$\begin{array}{l}\text { Knowledge of } \\
\text { classroom } \\
\text { assessment }\end{array}$} & \multirow{2}{*}{$\begin{array}{l}\text { Knowledge of learning } \\
\text { assessment procedures in } \\
\text { aspects of formative / } \\
\text { summative assessment, and } \\
\text { lesson evaluation planning in a } \\
\text { systematic, comprehensive, } \\
\text { continuous and objective } \\
\text { manner. }\end{array}$} & $\begin{array}{l}\text { e. Ability to make formative } \\
\text { and summative } \\
\text { iudoments }\end{array}$ & 6 \\
\hline & & $\begin{array}{l}\text { f. Ability to plan lesson } \\
\text { evaluations }\end{array}$ & 7 \\
\hline \multirow[t]{2}{*}{$\begin{array}{l}\text { Knowledge of } \\
\text { teaching methods }\end{array}$} & \multirow{2}{*}{$\begin{array}{l}\text { Knowledge of the use of } \\
\text { various relevant learning } \\
\text { methods to achieve learning } \\
\text { objectives which consist of } \\
\text { applying various teaching } \\
\text { methods and knowing when and } \\
\text { how to apply each of these } \\
\text { methods. }\end{array}$} & $\begin{array}{l}\text { g. Applying various } \\
\text { teaching methods, }\end{array}$ & 8 \\
\hline & & $\begin{array}{l}\text { h. Knowing when and how } \\
\text { to apply each appropriate } \\
\text { teaching method }\end{array}$ & 9 \\
\hline $\begin{array}{l}\text { Knowledge of } \\
\text { classroom }\end{array}$ & $\begin{array}{l}\text { Teacher knowledge in creating } \\
\text { conducive atmosphere of }\end{array}$ & $\begin{array}{l}\text { i. Creating conducive } \\
\text { atmosphere }\end{array}$ & 10 \\
\hline management & $\begin{array}{l}\text { learning activities to support the } \\
\text { educational interaction process } \\
\text { to achieve learning goals. }\end{array}$ & $\begin{array}{l}\text { j. Managing learning } \\
\text { activities }\end{array}$ & 11 \\
\hline
\end{tabular}

The data were analyzed by using T-test in order to determine the significance difference of the mean score of the mentoring learning. The prerequisite tests were done to 
determine the normality and homogeneity of the data variance. The data analysis was done with the assistance of Statistical Package for the Social Sciences (SPSS) of Windows version 22

\section{FINDINGS}

The results of pedagogical knowledge test among prospective teachers show that the scores of the pre-test and post-test of the conventional class were lower than the mentoring class. The conventional class had 28.03 for average pre-test score and 32.73 for post-test, while the mentoring class had 30.60 for the pre-test and 77.43 for the posttest (Table 5)

Table 5

The Score of Pre-Test and Post-Test of the Prospective Teacher for Pedagogical Knowledge

\begin{tabular}{llcccc}
\hline Model & $\mathrm{N}$ & \multicolumn{2}{c}{ Pre-test } & \multicolumn{2}{c}{ Post-test } \\
\cline { 3 - 6 } & & Mean & Std.Error & Mean & Std.Error \\
\hline Conventional & 30 & 28.03 & 1.519 & 32.73 & 1.794 \\
Mentoring & 30 & 30.60 & 1.764 & 77.43 & 1.142 \\
\hline
\end{tabular}

Based on the normality test with Kolmogorov-Smirnov One-Sample test, the results of pre-test and post-test scores did not show a significant difference where value of $p=.00$ $<.05$. It means the scores of the two tests were not normally distributed. In case of Homogeneity test, both scores showed homogeneous variance $(p>0.05)$. The score of the pretest was 0.326 and the post-test was 0.496 . Furthermore, the Mann-Whitney Utest was used to examine the mean of the two groups because the normality test was not achieved. The results of the Mann-Whitney U-test (Table 6) showed that the mentoring class and the conventional class had significant gap on the mean scores, so the results of this study indicated that there is a positive effect of mentoring model application in improving the prospective teachers' pedagogical knowledge $(p=.000<.05)$. Based on the score of Asymp. Sig. (2-tailed) from 0.095 in the pre-test, and .000 values in the post-test with $(\mathrm{p}=.000<.05)$, it can be concluded that the mean of pedagogical knowledge among prospective teachers using the mentoring model is higher than conventional models class.

Table 6

The Result of Mann-Whitney U-Test

\begin{tabular}{lcc}
\hline Group & $\mathrm{Z}$ & Asymp. Sig. (2-Tailed) \\
\hline $\begin{array}{l}\text { Pretest Experiment } \\
\quad \text { Control }\end{array}$ & -1.671 & .095 \\
$\begin{array}{l}\text { Posttest Experiment } \\
\quad \text { Control }\end{array}$ & -4.240 & .000 \\
\hline
\end{tabular}

\section{DISCUSSION}

Based on the results of research, the implementation of the mentoring model has a significant effect for the improvement of the prospective teachers' in case of their pedagogical knowledge. The importance of pedagogical knowledge for teachers is 
emphasized by Ball \& Bass (2000) that having knowledge of learning subject is very important as a teacher, but it is not enough for effective teaching. The teachers must know how to convey the learning subject and also know other supporting factors such as curriculum, students, and teaching strategies that also influence learning process. Iin line with this view, Arends (2008) points out that effective teachers must at least master the basic knowledge as a guide for their teaching practice. A good teacher must master the content (learning subject) and master teaching knowledge (Pedagogy). Pedagogy means efforts that can be done to help students to have better learning experience and solve problems in science (Enfield, 2007). It means pedagogical knowledge equips teachers to master the strategies to help their students to solve their science problems.

Considering the importance of the pedagogical knowledge components mentioned above, it is necessary to develop the training of pedagogical competencies for prospective teachers because most of them still lack of this competence. The low pedagogic knowledge due to lack of mentoring by higher education institutions among the prospective teachers so that many of them are failed to perform suitable teaching practice in classroom. If they are facilitated with suitable mentoring process, it can improve their teaching performance. The pedagogical competence can be improved through mentoring program as a process in providing assistance to prospective teachers to master specific skills and to assist them in preparing effective teaching process.

The research results by Mailani (2014) shows that mentoring provides significant increase in the components of the strategies selection and learning methods including steps and the time allocation. It has succeeded in improving teacher pedagogical competencies such as in the indicators formulation of learning objectives. Similar idea is expressed by Hudson, Skamp, \& Brooks, (2005); Erossman, Baldwin, \& Garry (2007) that a mentoring program is intended to allow prospective teacher to interact with someone who is more skilled and knowledgeable. Mentoring is fundamental in developing the teaching practices. As the important role of mentoring program, this study aimed at understanding the mentors' involvement in professional development programs to develop their pedagogical knowledge. The findings show that the mentoring model successfully guides pedagogical knowledge. Hudson, (2004) suggests that professional development programs that are well-structured with mentoring can support the quality of education to improve the teachers' performance. This is supported by several research results which conclude that teacher professional competence in Pedagogical Content Knowledge (PCK) is developed through a mentoring program (Olszewski, 2010; Mailani, 2014; Agustina, 2015; Purwianingsih, 2011). The factors that influence the development of it involve external and internal factors. The external factors refers to guidance model, lesson study activities, and intensive guidance. Meanwhile, the internal factors functions as the psychological effects that exist between teachers and students, as well as motivation from oneself to broaden their science knowledge, communication skills, and teaching experience (Rahmi, 2011; Riese, \& Reinhold, 2010).

According to Lai (2005), mentoring program plays an important role in strengthening the competence of new teachers and providing them opportunities for learning. In the 
educational context, mentoring must be run effectively and it requires complete structure and clear planning (Hudson, 2004). The development of teacher skills must be supported with an organized mentoring model, especially related to their teaching practice. Since the teachers have a very strategic role to determines the success of education, their pedagogical competencies must be improved. This competence is needed by the teacher because they do not only responsible for their students knowladge, but also the development of their students' personalities.

\section{CONCLUSION AND IMPLICATION}

Based on the research results, it can concluded that the implementation of mentoring models has significant effects in improving pedagogical knowledge of prospective teachers compared to the conventional models. The effective mentoring model is needed to support their pedagogical knowledge. The mentoring model proved effective for developing the performance of prospective teachers, especially for science field. In this case, pedagogical knowledge is important to be trained to prospective teachers' in order to prepare and equip them in managing effective learning. The suggestions based on this research results are the need of systematic mentoring model to develop the prospective teacher competence in the area of learning management, material design, evaluation and learning procedure. Moreover, the research results can be used as a reference for other educational institutions to make judgments about students' pedagogical competencies as well as to urge the implementation of mentoring model in the integrated curriculum.

\section{REFERENCES}

Agustina, P. (2015). Pengembangan Pck (Pedagogical Content Knowledge) Mahasiswa Calon Guru Biologi Fkip Universitas Muhammadiyah Surakarta Melalui Simulasi Pembelajaran. Jurnal Penelitian dan Pembelajaran IPA. JPPI, Vol. 1, No. 1, November 2015, Hal. 1-15.

Arends, R. (2008). Learning to Teach. New York: McGraw Hill.

Arnyana, I. B. P. (2007). Penerapan Model PBL Pada Pembelajaran Biologi Untuk Meningkatkan Kompetensi Dan Kemampuan Berpikir Kritis Siswa Kelas X SMA Nehgeri 1 Singaraja Tahun Pelajaran 2006/2007. http:// pasca.Undiksha.ac.id.

Ball, D. L., \& Bass, H. (2000). Interweaving content and pedagogy in teaching and learning to teach: Knowing and using mathematics. in J. Boaler (ed), multiple perspectives on the teaching and learning of mathematics (pp.83-104). Westport, CT: Albex.

Crawford, C. J. (2010). Manager's Guide to Mentoring. McGraw Hill.

Djamarah. (2010). Strategi Belajar Mengajar. Publisher. Rineka cipta.

Enfield, M. (2007) Content and Pedagogy: Intersection in the NSTA a Standards for Science Teacher Education.

Erossman, Baldwin, J., \& Garry, M. E. (2007). "Mentoring-A Proven Delinquency Prevention Strategy," Juvenile Justice Bulletin. 
Gay, L. R., \& Airasian, P. (1995) Educational Research: Competencies for Analysis and Application (6th ed.). Upper Saddle River, NJ: Merrill/Prentice Hall.

Hudson, P. (2004) Specific mentoring: a theory and model for developing primary science teaching practices, European Journal of Teacher Education, 27(2), 139-146.

Hudson, P., Skamp, K., \& Brooks, L. (2005) Development of an instrument: mentoring for effective primary science teaching, Science Education, 89(4), 657-674.

Koehler, M. J., Mishra, P., Akcaoglu, M., \& Rosenberg, J. M. (2013). The technological pedagogical content knowledge framework for teachers and teacher educators. ICT integrated teacher education models (pp. 1-8). New Delhi, India: Commonwealth Educational Media Center For Asia.

Kusaeri, \& Aditomo, A. (2018). Pedagogical beliefs about critical thinking among indonesian mathematics pre-service teachers. International Journal of Instruction, 12(1).

Lai, E. (2005). Mentoring for In-service Teachers in a Distance Teacher Education Programme: Views of Mentors, Mentees and University Teachers. Paper presented at the Australian Association for Research in Education International Education Research Conference, Parramatta.

Lee, Y. A., \& Takahashi, A. (2011). Lesson plans and the contingency of classroom interactions. Human Studies, 34(2), 209-227.

Mailani, E. (2014) Upaya Pembinaan Kompetensi Pedagogik Guru Dalam Menyusun Rencana Pelaksanaan Pembelajaran Melalui Kegiatan Pendampingan (Mentoring). School Education Journal PGSD FIP UMIMED, 1(2). 35-41

Mishra, P., \& Mattew J. K. (2006). Technological Pedagogical Content Knowledge: A Framework for Teacher Knowledge. Teachers College Record, 108(6), 1017-1054.

Mulyasa, E. (2004). Kurikulum berbasis kompetensi. Bandung. Remaja Rosda Karya.

Olszewski, J. (2010). The Impact of Physics Teachers' Pedagogical Content Knowledge on Teacher Action and Student Outcomes, Logos Verlag Berlin GMBH, Berlin.

Purwianingsih, W. (2011). Pengembangan Program Pembekalan Pedagogical Content Knowledge (PCK) Bioteknologi Melalui Perkuliahan Kapita Selekta Biologi. Tesis. Universitas Pendidikan Indonesia, Bandung.http://repository.upi.edu/7553/. Retrived on August 03, 2016.

Rahmi, S. (2011). "Strengthening Pedagogic Content Knowledge in Teacher Education Curriculum". Makalah dalam Proceeding International Seminar of Education Pedagogical Content Knowledge. UPI-Bandung.

Ramdiah, S., Abidinsyah, Royani, M., \& Husamah. (2019). Understanding, Planning, and Implementation of HOTS by Senior High School Biology Teachers in BanjarmasinIndonesia. International Journal of Instruction, 12(1). 
Riese, J., \& Reinhold, P. (2010). Measuring physics student teachers' pedagogical content knowledge as an indicator of their professional action competence. Dalam M. F.

Sarwono, J. (2015). SPSS 22. Yogyakarta: ANDI Publisher.

Schmidt, D. A., Evrim B., Ann D., Punya, M., Matthew, J. K., \& Tae, S. S. (2009). Technological Pedagogical Content Knowledge (TPACK): The Development and Validation of an Assessment Instrument for Preservice Teachers. Journal of Research on Technology in Education (JRTE), 42(2), 123-149.

Skilling, K., Bobis, J., Martin, A. J., Anderson, J., \& Way, J. (2016). What secondary teachers think and do about student engagement in mathematics. Mathematics Education Research Journal, 28, 545-566. 